\title{
Pengaruh Pengetahuan Auditor, Pengalaman Auditor, dan Tekanan Ketaatan Terhadap Audit Judgment pada Kantor Akuntan Publik di Kota Medan
}

\author{
Krishna Wati $^{1 *}$, Desnitar Manao ${ }^{2}$, Irene Srimawati Doloksaribu ${ }^{3}$, Wilsa Road B. Sitepur ${ }^{4}$ \\ Universitas Prima Indonesia ${ }^{1,2,3,4}$ \\ krishna_ina98@yahoo.com, Manao_desnitar@yahoo.co.id, irenesrimawati24@gmail.com, \\ will_better_sitepu@yahoo.co.id
}

*Corresponding Author

Submitted: August 21, 2020

Accepted : September 10, 2020

Published: 01/Februari/2021

\begin{abstract}
In making the right judgment, the public accountant must have a lot of knowledge and experience so that when assessing an entity, the decisions made are not wrong. And in making decisions, it should not be influenced by the entity or its own superiors. There is a case in 2018 that happened to two public accountants who did not understand how to take the right judgment in carrying out the task of auditing the annual report to PT Sunprima Nusantara Financing (SNP Finance). Based on this case, this research aims to analyze the making of audit judgment in the city of Medan. It must be influenced by the existence of knowledge, experience and obedience pressure so that cases like the above do not occur in the city of Medan. In collecting the questionnaire data using a Likert scale and choosing multiple linear regression analysis as a research hypothesis testing. The results showed that the determination coefficient test resulted in a percentage of $54 \%$ with the conclusion that audit judgment can be explained by auditor knowledge, auditor experience, and pressure.
\end{abstract}

Keywords: Audit Judgment, Auditor Knowledge, Auditor Experience, Obedience Pressure, Public Accounting Firm.

\section{PENDAHULUAN}

Sebagai seorang akuntan publik haruslah memiliki pengetahuan dan pengalaman yang sangat banyak sehingga saat menilai suatu entitas, keputusan yang dibuat tidaklah keliru dan disertai bekerja secara jujur dan memiliki independensi dalam pengambilan keputusan tanpa dipengaruhi oleh pihak entitas ataupun atasannya sendiri. Seperti dibawah ini terdapat kasus dimana seorang auditor tersebut kurang memahami bagaimana cara mengambil keputusan yang tepat. Kasus ini terjadi pada tahun 2018 kemarin, menjerat dua Akuntan Publik berinisial M dan MS. Kedua Akuntan Publik yang berkantor di Deloitte Indonesia yang bertugas untuk mengaudit laporan keuangan tahunan pada PT Sunprima Nusantara Pembiayaan (SNP Finance) dengan memberikan opini WTP (Wajar Tanpa Pengecualian). Setelah diselidiki oleh Lembaga OJK (Otoritas Jasa Keuangan) membuktikan bahwasanya sajian laporan keuangan yang dikeluarkan oleh SNP Finance tidak sesuai dengan kondisi keadaan perusahaan yang mengakibatkan pihak perbankan mengalami kerugian atas ketidak jujuran laporan yang disajikan oleh SNP Finance. Dari kasus ini juga Deloitte Indonesia mendapatkan sanksi administratif yaitu berupa larangan untuk menambah jumlah klien baru berlaku di sektor jasa keuangan, kedua akuntan publik mendapatkan saksi pencabutan izin selama satu tahun untuk tidak memberikan jasa audit kepada pihak - pihak entitas jasa keuangan. Sedangkan untuk SNP Finance sendiri mendapatkan sanksi berupa pembekuan izin usaha.

Berdasarkan kasus yang menimpa kedua akuntan publik tersebut, dapat dinilai bahwasannya kedua Akuntan publik tersebut gagal membuat judgment yang tepat terhadap laporan keuangan SNP Finance. Kegagalan membuat Judgment ini dapat disebabkan karena Akuntan Publik tersebut memiliki pengetahuan yang minim terhadap SPAP (Standar Profesional Akuntan Publik) serta 
kurangnya pengalaman sehingga gagal mendeteksi kecurangan yang terjadi pada SNP Finance. Jika dalam kasus diatas terdapat tekanan ketaatan maka dapat dipertanyakan tingkat integritas dan independensi yang dimiliki telah menyimpang dari standar profesional sehingga audit judgment yang dibuat sangat diragukan.

Semakin bagus kualitas Judgment yang diberikan seorang auditor dapat dipengaruhi karena banyaknya pengetahuan yang didapatkannya. Praktek yang didapat dari pengalaman seorang auditor selama bekerja menjadi salah satu point penting dalam mengembangkan potensi yang dimilikinya selain itu pengalaman - pengalaman yang dimilikinya dapat membantu seorang auditor dalam membuat judgment yang baik dan dapat dipertanggung jawabkan kebenarannya. Legitimate power adalah suatu fenomena sosial di dalam dunia kerja dimana kekuasaan (otoritas) individu maupun kelompok yang dapat memicu individu maupun kelompok lainnya sehingga merubah keputusannya. Legitimate power yang ada menimbulkan tekanan ketaatan (obedience pressure) dalam diri seorang auditor dimana akan merasa tertekan dalam menjalankan tugasnya diakibatkan karena apa yang dilakukan selama menjalankan tugas yang didapatkan bertentangan dengan etika profesi akuntan yang dapat mengakibatkan audit judgment yang dibuat tidak tepat.

\section{STUDI LITERATUR}

\section{Teori pengaruh pengetahuan auditor terhadap audit judgment}

Pengetahuan seorang auditor akan menjadi kunci penting dalam membentuk suatu keputusan, disamping itu seorang auditor yang sanggup mengembangkan pengetahuan akan mengantongi wawasan yang sangat luas dalam dunia praktik akuntansi dan menguasai teknik audit dalam pembuatan judgment (Tampubolon, 2018). Pengetahuan yang terus dikembangkan dapat meningkatkan pemahaman intelektual yang baik dalam menyelesaikan tugas secara efektif dan menjadi kunci dalam pengambilan keputusan audit (Yendrawati \& Mukti, 2015). Akan tetapi meskipun auditor memiliki memiliki banyak wawasan dalam dunia audit, tidak menjamin bahwa audit judgment yang diberikan tepat jika dalam proses penyelesaian tugas audit diikuti oleh adanya tekanan ketaatan (obedience pressure) (Ginting, 2019).

H1 : Diperoleh pengaruh yang bernilai positif beserta signifikan variabel pengetahuan auditor kepada variabel audit judgment.

\section{Teori pengaruh pengalaman auditor terhadap audit judgment}

Pengalaman seorang dapat diartikan proses perkembangan pola tingkah laku yang didasari atas pemahaman yang didapat dalam pendidikan formal dan non - informal. Pengalaman yang banyak menjadi acuan dalam melaksanakan tugas pengauditan dengan baik sehingga menjadi acuan dalam pembuatan judgment (Riantono, 2018). Semakin luas pemahaman audit yang didapatkan dari hasil pengalaman yang didapatkan semasa bekerja akan meningkatkan ketepatan audit judgment (Pardomuan Ritonga, 2019). Namun ada pihak yang berpendapat bahwa dalam pembuatan audit judgment tidak dapat dipengaruhi oleh adanya pengalaman (Alamri et al., 2017). H2 : Diperoleh pengaruh yang bernilai positif beserta signifikan variabel pengalaman auditor

kepada variabel audit judgment.

\section{Teori pengaruh tekanan ketaatan terhadap audit judgment}

Tekanan ketaatan membuat pertentangan terhadap integritas dan independensi seorang auditor melanggar norma - norma serta nilai yang terkandung dalam standar profesional, menekan auditor yang sedang bertugas untuk memenuhi apa yang diharapkan mengakibatkan penurunan kualitas audit judgment (Muslim et al., 2018). Pengaruh tekanan ketaatan biasanya di alami seorang auditor pemula, instruksi atasan terhadap bawahan yang memiliki otoritas akan sangat berpengaruh untuk melanggar standar etika dan profesionalisme sehingga tidak dapat menjamin kebenaran atas audit judgment (Agustini \& Merkusiwati, 2016). Berdasarkan logika masyarakat bila seseorang mendapatkan tekanan baik dari pihak atasan atau pun pihak entitas dapat memicu gejala stress sehingga teori obedience pressure dapat tercipta. Jika tidak ada jiwa keberanian didalam diri seorang auditor dan bersikap disfungsional didalam menyelesaikan tugas audit hal ini akan menyebabkan penurunan kualitas audit judgment yang diberikan (Kadir \& Hasibuan, 2017) 
H3 : Diperoleh pengaruh yang bernilai positif beserta signifikan variabel tekanan ketaatan kepada variabel audit judgment.

\section{Pendekatan dan jenis penelitian}

\section{METODE}

Pendekatan kuantitatif dipilih dalam penelitian ini, disamping itu teknik pengumpulan data penelitian menggunakan teknik random sampling dengan pengumpulan sampel menggunakan butir - butir pernyataan yang dimuat didalam kuesioner (angket). Penyerahan kuesioner dititipkan disetiap kantor akuntan publik dimana para akuntan publik tersebut bersedia untuk dijadikan sebagai responden dalam penelitian ini. Serta tolak ukur responden atas jawaban yang diberikan auditor terhadap setiap variabel yang kami teliti, kami menggunakan skala Likert. Penggunaan jenis data dapat dibuat dalam bentuk deskriptif yang berlandaskan atas filsafat positivism dan sumber data merupakan data kepada auditor primer, dengan kuesioner sebagai pelantara yang dibagikan secara langsung.

\section{Populasi dan Sampel}

Pada penelitian ini peneliti mencakup seluruh populasi kantor akuntan publik terletak dikota Medan, sedangkan pihak - pihak akuntan yang bersedia untuk dijadikan sebagai responden penelitian ini terdiri dari 6 (enam) kantor akuntan publik diantaranya kantor akuntan publik Drs. Katio \& Rekan, kantor akuntan publik Joachim Poltak Lian Michell \& Rekan (Cabang), kantor akuntan publik Fachrudin \& Mahyuddin, kantor akuntan publik Darwin S. Meliala, kantor akuntan publik Drs. Syamsul Bahri,Mm.Ak \& Rekan, serta kantor akuntan publik Drs. Selamat Sinurya \& Rekan.

\section{Teknik Analisis Data}

Seperti penelitian - penelitian sebelumnya, model analisis linear berganda menjadi pilihan yang tepat untuk mengukur seberapa besar pengaruh bernilai positif signifikan yang ditimbulkan antara variabel bebas kepada variabel terikat. Disamping itu peneliti juga menggunaan uji asumsi klasik untuk mempertegas hubungan antara variabel bebas kepada variabel terikat. Dan penggunaan koefisien determinasi dibutuhkan untuk meninjau seberapa besar persentasi yang dapat mengungkapkan variabel - variabel bebas yang sedang diteliti dapat memperjelas kondisi variabel terikat.

Model analisis linear berganda : $\mathrm{Y}=\mathrm{a}+\mathrm{b}_{1} \mathrm{X}_{1}+\mathrm{b}_{2} \mathrm{X}_{2}+\mathrm{b}_{3} \mathrm{X}_{3}+\mathrm{e}$

$\mathrm{Y}=$ Audit judgment

$\mathrm{a}=$ Konstanta

$\mathrm{X}_{1}=$ Pengetahuan auditor

$\mathrm{X}_{2}=$ Pengalaman auditor

$\mathrm{X}_{3}=$ Tekanan Ketaatan (Obedience pressure)

$\mathrm{e}=$ standart error

\section{Uji Validitas}

\section{HASIL}

Pengujian validitas yang dilaksanakan untuk membantu mengungkapkan valid atau tidak validnya suatu pernyataan dari butir - butir pernyataan yang telah tersaji dapat menggambarkan pengetahuan, pengalaman serta tekanan ketaatan yang dimiliki dan dialami oleh responden dalam membuat audit judgment yang baik. Dan dari olah data yang dilakukan mendapatkan data valid disetiap variabel yang diuji.

\section{Uji Reliabilitas}

Pengujian reliabilitas dilakukan untuk membantu peneliti untuk menggambarkan bahwa jawaban yang dihadirkan oleh para responden di setiap butir - butir pernyataan yang tersaji dijawab secara konstan dan cenderung stabil. Tolak ukur uji ini menggunakan Conbanch Alpha $>0.60$. Dari hasil pengujian yang menerangkan bahwa setiap jawaban per - item yang dijawab oleh responden terhadap pernyataan yang tersaji memiliki nilai konstan dan stabil. 


\section{Uji Normalitas}

Untuk pengujian normalitas ini dapat dijelaskan dengan dua metode berupa bentuk grafik dan uji statistik. Dari hasil output penggunaan metode ini dapat menerangkan jika dalam persamaan regresi yang sedang diteliti menghasilkan distribusi normal pada setiap variabel bebas yang berhubungan dengan variabel terikat.

\section{a. Analisa Grafik}

Pengujian Normalitas yang paling mudah untuk menggambarkan bahwasannya persamaan regresi memiliki residual normal. Dan hasil akhir dari analisa grafik berupa bentuk grafik histogram dan grafik Probability Plots.

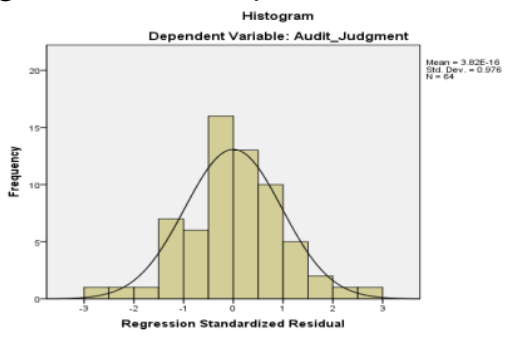

Gambar 1: Hasil Uji Normalitas dengan Grafik histogram Sumber : Hasil output SPSS 19

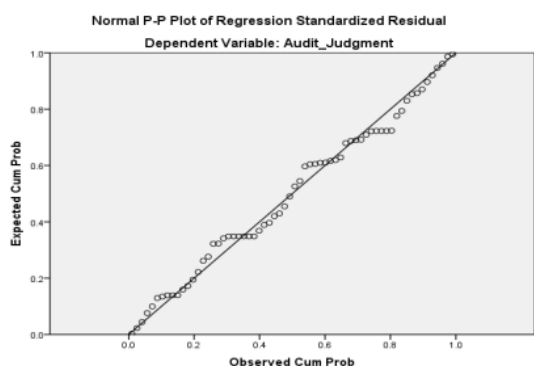

Gambar 2: Hasil Uji Normalitas dengan Grafik Normal probability plots Sumber : Hasil output SPSS 19

Berdasarkan hasil data output SPSS, dari hasil pengujian ini menampilkan bahwa gambar tampilan pada grafik histogram memiliki pola distribusi yang melenceng ke kanan, sehingga dapat dikatakan bahwa grafik histogram tersebut berdistribusi normal. Sedangkan pada grafik Probability Plots menampilkan pola bercak - bercak yang hampir seluruh pola tersebut mengikuti garis diagonal yang dapat dilihat dari skema grafik yang ada di atas, sehingga dapat disebutkan bahwa grafik Probabity Plots juga memiliki distribusi yang bersifat normal.

\section{b. Uji Statistik}

Pedoman untuk melihat bahwa hasil uji statistik bersifat normal apabila jika dalam uji ini menghasilkan nilai signifikan diatas 0.05 . Pada uji statistik ini peneliti menggunakan uji Kolgomorov Smirnov dan memiliki nilai signifikan 0.757 maka memenuhi uji statistik yang diharapkan dan memiliki distribusi yang normal.

Tabel 1.Uji Kolmogorov - Smirnov

Sumber : Hasil output SPSS 19

One-Sample Kolmogorov-Smirnov Test

\begin{tabular}{|c|c|}
\hline & $\begin{array}{r}\text { Unstandardized } \\
\text { Residual }\end{array}$ \\
\hline$N$ & 64 \\
\hline Mean & .0000000 \\
\hline $\begin{array}{rr}\text { Parameters }{ }^{a}, b & \text { Std. } \\
\text { Deviation }\end{array}$ & 5.38613418 \\
\hline Absolute & .084 \\
\hline $\begin{array}{l}\text { Most Extreme } \\
\text { Differences }\end{array}$ & .084 \\
\hline Negative & -.068 \\
\hline Kolmogorov-Smirnov Z & 672 \\
\hline Asymp. Sig. (2-tailed) & .757 \\
\hline
\end{tabular}

a. Test distribution is Normal.

b. Calculated from data. 
Owner: Riset \& Jurnal Akuntansi

e-ISSN : 2548-9224|p-ISSN : 2548-7507

Volume 05 Nomor 01, Februari 2021

\section{Uji Multikolinieritas}

Pengujian Multikolinieritas digunakan untuk meneliti bahwa tidak ada hubungan pada setiap variabel bebas memiliki hubungan korelasi di dalam regresi linear. Jika terdapat adanya hubungan korelasi disetiap variabel bebas maka dapat dikatakan variabel tersebut bersifat orthogonal (memiliki nilai 0). Selain itu untuk menentukan bahwa setiap variabel bebas tidak memiliki korelasi dapat dilihat menggunakan perbandingan :

VIF (Inflation Factor) $\leq \mathbf{1 0}$, Tolerance $\geq \mathbf{0 . 1 0}$, maka gejala Multikolinieritas tidak terlihat didalam persamaan regresi yang diteliti. Hasil data output SPSS menyatakan bahwa variabel bebas yang tidak memiliki gejala multikolinieritas yang dapa dilihat dari VIF serta Tolerance.

Tabel 2. Uji Multikolinieritas

Sumber : Hasil Output SPSS 19

Coefficients

\begin{tabular}{|cl|c|c|}
\hline \multirow{2}{*}{} & \multirow{2}{*}{ Model } & \multicolumn{2}{|c|}{$\begin{array}{c}\text { Collinearity } \\
\text { Statistics }\end{array}$} \\
\cline { 3 - 4 } & (Constant) & Tolerance & VIF \\
\hline 1 & & \\
& Pengetahuan_Auditor & .466 & 2.146 \\
& Pengalaman_Auditor & .518 & 1.931 \\
& Tekanan_Ketaatan & .854 & 1.171 \\
\hline
\end{tabular}

a. Dependent Variable: Audit_Judgment

\section{Uji Heteroskedastisitas}

Untuk memahami hasil uji heteroskedestisitas dapat dilihat melalui bentuk grafik Scatterplot dan uji Glesjer. Adapun uji heteroskedestisitas dilakukan untuk melihat dan menilai varians yang terdapat di dalam regresi linear yang sedang diobservasi memiliki kesamaan dengan variabel yang lain (Homoskedatisitas).

\section{a.Analisa grafik Scatterplot}

Hasil output SPSS pada grafik Scaterplot tampak bahwa setiap pola bercak - bercak tidak membentuk suatu objek melainkan menyebar di atas origin pada sumbu Y secara acak, sehingga dapat dikatakan bahwa grafik Scatterplot bersifat Homoskedatisitas (tidak memiliki gejala heteroskedatisitas).

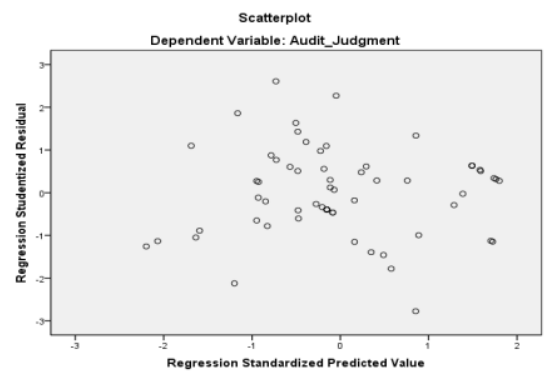

Gambar 3 : Hasil Uji Heteroskedatisitas dengan Grafik Scatterplot Sumber : Hasil Output SPSS 19

\section{b. Uji Glesjer}

Hasil dari output SPSS mengenai uji glesjer menjadi bukti pedukung tambahan bahwa nilai varians yang terdapat didalam regresi linear memiliki kesamaan antar variabel, dengan tingkat signifikan diatas 0.05 . Dan nilai varians yang terdapat didalam regresi linear menunjukan sifat homoskedatisitas. 
Tabel 3. Uji Heteroskedastisitas mengguunakan Uji Glesjer

Sumber : Hasil Output SPSS 19

Coefficients $^{\mathrm{a}}$

\begin{tabular}{|cl|c|}
\hline \multirow{4}{*}{ Model } & Sig. \\
\hline \multirow{4}{*}{1} & (Constant) & .068 \\
& Pengetahuan_Auditor & .376 \\
& Pengalaman_Auditor & .786 \\
& Tekanan_Ketaatan & .339 \\
\hline
\end{tabular}

a. Dependent Variable: RES_2

\section{Hasil Analisa Data Penelitian}

Penggunaan analisa linear berganda merupakan serangkaian uji akhir untuk meninjau seberapa besar pengaruh variabel bebas memiliki kontribusi sangat berpengaruh kepada variabel terikat. Dengan Rumus : $\mathrm{Y}=\mathrm{a} 0+\mathrm{b}_{1} \mathrm{X}_{1}+\mathrm{b}_{2} \mathrm{X}_{2}+\mathrm{b}_{3} \mathrm{X}_{3}+\mathrm{e}$

Tabel 4. Model Penelitian

Sumber : Hasil Output SPSS 19

Coefficients $^{\mathrm{a}}$

\begin{tabular}{|c|c|c|c|c|}
\hline & \multirow{2}{*}{ Model } & \multicolumn{2}{|c|}{$\begin{array}{l}\text { Unstandardized } \\
\text { Coefficients }\end{array}$} & \multirow{2}{*}{$\begin{array}{c}\text { Standardized } \\
\text { Coefficients } \\
\text { Beta }\end{array}$} \\
\hline & & B & $\begin{array}{l}\text { Std. } \\
\text { Error }\end{array}$ & \\
\hline & (Constant) & -6.056 & 7.124 & \\
\hline & Pengetahuan_Auditor & .300 & .105 & .367 \\
\hline & Pengalaman_Auditor & .705 & .190 & .452 \\
\hline & Tekanan_Ketaatan & -.044 & .057 & -.073 \\
\hline
\end{tabular}

a. Dependent Variable Audit_Judgment

Dan data output SPSS penelitian ini memiliki persamaan linear sebagai berikut :

$\mathrm{Y}=-6.056+0.300$ (pengetahuan auditor) +0.705 (pengalaman auditor) -0.044 (tekanan ketaatan)

$+\mathrm{e}$

Dari persamaan diatas nilai pada kostanta menghasilkan nilai negatif yaitu sebesar -6.056 , sehingga menggambarkan apabila nilai yang terdapat dalam variabel bebas yaitu pengetahuan auditor (X1), pengalaman auditor (X2) dan tekanan ketaatan (X3) bernilai nol (0) maka variabel terikat pada audit judgment $(\mathrm{Y})$ akan bernilai negatif. Sedangkan jika nilai konstanta bernilai nol (0), dengan nilai koefisien yang terdapat dalam variabel pengetahuan auditor menghasilkan nilai 0.300 dan untuk nilai koefisien pengalaman auditor menghasilkan nilai sebesar 0.705 yang masing - masing bernilai positif, dapat diartikan setiap terjadi penambahan didalam pengetahuan auditor dan pengalaman auditor maka akan menambah nilai terhadap audit judgment sesuai dengan nilai koefisien tersebut. Nilai koefisien pada tekanan ketaatan menghasilkan nilai negatif yaitu sebesar 0.044 sehingga dapat diartikan bahwa setiap adanya penambahan didalam tekanan ketaatan akan diikuti dengan menurunnya nilai yang terdapat didalam audit judgment sesuai dengan nilai koefisien tersebut.

\section{Koefisien Determinasi Hipotesis}

Dari output SPSS menghasilkan nilai determinasi (R) adalah sebesar 0.540 atau dapat dikatakan sebesar 54\% dengan kesimpulan dalam penelitian ini bahwa variabel - variabel bebas (pengetahuan auditor, pengalaman auditor, dan tekanan ketaaan) dapat menerangkan keberadaan variabel terikat (audit judgment). Sedangkan untuk 46\% merupakan variabel yang tidak diteliti misalkan independensi, gender dan locus focus of control. 
Tabel 5. Koefisien Determinasi Hipotesis

Sumber : Hasil output SPSS 19

Model Summary ${ }^{\mathrm{b}}$

\begin{tabular}{|c|c|c|c|c|}
\hline Model & $\mathrm{R}$ & $\mathrm{R}$ Square & $\begin{array}{c}\text { Adjusted R } \\
\text { Square }\end{array}$ & $\begin{array}{c}\text { Std. Error of } \\
\text { the Estimate }\end{array}$ \\
\hline 1 & $.735^{\mathrm{a}}$ & .540 & .517 & 5.51915 \\
\hline
\end{tabular}

a. Predictors: (Constant), Tekanan_Ketaatan, Pengalaman_Auditor,

Pengetahuan_Auditor b. Dependent Variable: Audit_Judgment

\section{Pengujian Hipotesis secara Simultan (Uji F).}

Uji F (uji simultan) ini dapat membantu peneliti untuk mengetahui bahwa dalam variabel variabel bebas (pengetahuan auditor, pengalaman auditor, dan tekanan ketaatan) secara keseluruhan memberikan pengaruh positif terhadap variabel terikat (audit judgment), dengan pedoman bahwa nilai $\mathrm{F}$ hitung $>\mathrm{F}$ tabel dan level sigifikan $<0.05$. nilai $\mathrm{F}$ tabel mendapat nilai sebanyak 2.76 dan menghasilkan perbandingan $\mathrm{F}$ hitung $23.453>\mathrm{F}$ tabel 2.76 dan tingkat signifikan yang dihasilkan pada data diatas sebesar $0.000<0.05$ dengan ini menyatakan bahwa variabel - variabel bebas berdasarkan uji simultan memiliki kontribusi berpengaruh terhadap variabel terikat.

Tabel 6. Hasil Uji F

Sumber : Hasil output SPSS 19

ANOVA $^{\mathrm{b}}$

\begin{tabular}{|cc|c|c|c|c|c|}
\hline Model & & $\begin{array}{c}\text { Sum of } \\
\text { Squares }\end{array}$ & Df & $\begin{array}{c}\text { Mean } \\
\text { Square }\end{array}$ & F & Sig. \\
\hline \multirow{2}{*}{1} & Regression & 2143.202 & 3 & 714.401 & 23.453 & $.000^{\mathrm{a}}$ \\
& Residual & 1827.658 & 60 & 30.461 & & \\
\hline & Total & 3970.859 & 63 & & & \\
\hline
\end{tabular}

a. Predictors: (Constant), Tekanan_Ketaatan, Pengalaman_Auditor,

Pengetahuan_Auditor b. Dependent Variable: Audit_Judgment

\section{Pengujian Hipotesis secara Parsial (Uji t)}

Pengujian hipotesis parsial memiliki peranan untuk meninjau setiap variabel bebas (pengetahuan auditor, pengalaman auditor, dan tekanan ketaatan) mempunyai kontribusi pengaruh kepada variabel terikat (audit judgment).

Tabel 7. Hasil Uji t

Sumber : Hasil output SPSS 19

Coefficients $^{\mathrm{a}}$

\begin{tabular}{|c|c|c|c|c|c|}
\hline \multirow{2}{*}{ Model } & \multicolumn{2}{|c|}{$\begin{array}{l}\text { Unstandardized } \\
\text { Coefficients }\end{array}$} & \multirow{2}{*}{$\begin{array}{c}\begin{array}{c}\text { Standardized } \\
\text { Coefficients }\end{array} \\
\text { Beta }\end{array}$} & \multirow{2}{*}{$\mathrm{t}$} & \multirow{2}{*}{ Sig. } \\
\hline & B & $\begin{array}{l}\text { Std. } \\
\text { Error }\end{array}$ & & & \\
\hline (Constant) & -6.056 & 7.124 & & -.850 & .399 \\
\hline Pengetahuan_Auditor & .300 & .105 & .367 & 2.857 & .006 \\
\hline Pengalaman_Auditor & .705 & 190 & 452 & 3.718 & .000 \\
\hline Tekanan_Ketaatan & -.044 & .057 & -.073 & -.769 & .445 \\
\hline
\end{tabular}

a. Dependent Variable: Audit_Judgment

Dari data diatas, untuk mengetahui nilai df (drajat kebebasan) dengan rumus n-k-1 menghasilkan df sebesar 60 dengan tingkat signifikan yang menjadi patokan sebesar alpha 0.05 sehingga menghasilkan nilai t tabel 2.00030, dengan perbandingan bahwa H1 diterima dimana dapat dilihat nilai t hitung 2.857>2.00030 t tabel dan level signifikan yang dihasilkan pada data 
adalah $0.006<0.05$, dengan ini menyatakan bahwa variabel X1 (pengetahuan auditor) memiliki kontribusi berpengaruh terhadap variabel $\mathrm{Y}$ (audit judgment). $\mathrm{H} 2$ diterima dimana dapat dilihat nilai t hitung 3.718>2.00030 t tabel dan level signifikan yang dihasilkan pada data adalah $0.000<0.05$ dengan ini menyatakan bahwa variabel X2 (pengalaman auditor) memiliki kontribusi berpengaruh terhadap variabel Y (audit judgment). H3 ditolak dimana dapat dilihat nilai t hitung $-0.769<2.00030 \mathrm{t}$ tabel dan level signifikan yang dihasilkan pada data adalah $0.445>0.05$ dengan ini menyatakan bahwa variabel X3 (tekanan ketaatan) tidak memiliki kontribusi berpengaruh terhadap variabel Y (audit judgment).

\section{PEMBAHASAN \\ Pengaruh Pengetahuan Auditor terhadap Audit Judgment}

Setelah meninjau dari hasil penelitian dengan pengujian secara parsial, dengan ini dapat menyatakan bahwa hipoteris (H1) dapat diterima secara mutlak dikarenakan nilai signifikan yang dihasilkan tidak melewati nilai alpha yang suda ditetapkan sebesar 0.05. Dengan kesimpulan bahwa pengetahuan auditor dapat memberikan kontribusi berpengaruh dalam pembuatan judgment yang tepat. Adapun hasil penelitian terdahulu yang mengungkapkan hasil yang selaras dengan penelitian ini yaitu penelitian yang dijalankan oleh (Putri, 2017),(Yolanda, 2017), (Apriliastuty et al., 2019) Pengalaman yang didapat dari penyelesaian tugas - tugas audit dan terus - menerus diasah diikuti dengan partisipasi dalam pelatihan akan semakin menambah pengetahuan terhadap mendeteksi kekeliruan audit, mempermudah auditor dalam menyelesaikan tugas dan dari tingkat pemahamannya dalam menyelesaikan pekerjaan auditor itu sendiri, dengan sumber pengetahuan yang luas dapat menjadi modal bagi auditor dalam membuat audit judgment yang seksama dan selektif.

\section{Pengaruh Pengalaman Auditor terhadap Audit Judgment}

Setelah meninjau dari hasil penelitian dengan pengujian secara parsial, dengan ini dapat menyatakan bahwa hipoteris $(\mathrm{H} 2)$ dapat diterima secara mutlak dikarenakan nilai signifikan yang dihasilkan tidak melewati nilai alpha yang sudah ditetapkan sebesar 0.05. Dengan kesimpulan bahwa pengalaman auditor dapat memberikan kontribusi berpengaruh dalam pembuatan judgment yang tepat. Adapun hasil penelitian terdahulu yang mengungkapkan hasil yang selaras dengan penelitian ini yaitu penelitian yang dijalankan oleh (Maryani \& Ilyas, 2017), (Rosadi, 2017), dan (Ismunawan \& Triyanto, 2020). Banyaknya pengetahuan yang didapatkan dari pengalaman yang ada membuat seorang auditor berbeda dengan auditor lainnya sehingga audit judgment yang dibuat berbeda pula. Bila pada saat mengerjakan tugas audit dan dihadapkan pada penemuan salah saji material yang terdapat didalam laporan keuangan, pengalaman yang didapat oleh auditor semasa beliau bekerja akan sangat membantu auditor lebih selektif untuk membuat audit judgment. menyampaikan bahwa kualitas audit judgment yang dihasilkan akan semakin bermutu jika seorang auditor memiliki pengalaman yang banyak dan mampu mengaplikasikannya dalam menjalankan tugas audit.

\section{Pengaruh Tekanan Ketaatan terhadap Audit Judgment}

Setelah meninjau dari hasil penelitian dengan pengujian secara parsial, dengan ini dapat menyatakan bahwa hipoteris (H3) ditolak secara mutlak dikarenakan nilai signifikan yang dihasilkan tidak melewati nilai alpha yang sudah ditetapkan sebesar 0.05. Dengan kesimpulan bahwa tekanan ketaatan yang bersumber dari perintah atasan atau permintaan klien tidak akan mampu mempengaruhi auditor untuk mengambil judgment dengan bijak. Adapun hasil penelitian terdahulu yang mengungkapkan hasil yang selaras dengan penelitian ini yaitu penelitian yang dijalankan oleh (Indah Sari \& Ruhiyat, 2017),(Dana, 2019), serta (Mukhyi \& Hendry, 2019). Bekerja secara independent yang dilakukan oleh auditor dapat mencerminkan bahwa auditor mampu menegakkan rasa profesionalisme dalam dunia kerja, seorang auditor senior mempunyai segudang pengalaman dan jenjang pendidikan yang tinggi akan bersikap profesional saat bekerja dan memiliki keberanian untuk menentang dengan tegas jika dihadapkan pada kecurangan audit dengan tidak mematuhi perintah atasan maupun permintaan klien meskipun resiko yang diterima 
adalah kehilangan pekerjaan tidak akan membuat seorang auditor gentar untuk membuat audit judgment yang tepat.

\section{KESIMPULAN}

Berdasarkan hasil penelitian yang telah dilakukan pada kantor akuntan publik yang berada di Kota Medan, Dalam pengujian parsial mengungkapkan bahwa pengetahuan auditor dan pengalaman auditor memiliki pengaruh signifikan terhadap audit judgment, sedangkan tekanan ketaatan memiliki hasil tidak memiliki pengaruh signifikan terhadap audit judgment, hal ini menjelaskan bahwa para akuntan publik yang bekerja diwilayah Kota Medan dapat membuat audit judgment dengan benar. Pengetahuan dan pengalaman akan senantiasa menjadi faktor pendorong bagi auditor dalam pembuatan audit judgment serta jika tidak adanya tekanan ketaatan yang dirasakan auditor pada saat menyelesaikan tugas audit maka audit judgment yang dihasilkan akan semakin akurat karena tidak ada campur tangan dari pihak manapun.

\section{REFERENSI}

Agustini, N., \& Merkusiwati, N. (2016). Pengaruh Tekanan Ketaatan, Senioritas Auditor Dan Tekanan Anggaran Waktu Terhadap Audit Judgment. E-Jurnal Akuntansi, 15(1), 433-462.

Alamri, F., Nangoi, G. B., \& Tinangon, J. (2017). Pengaruh Keahlian, Pengalaman, Kompleksitas Tugas dan Independensi terhadap Audit Judgment Auditor Internal pada Inspektorat Provinsi Gorontalo. Jurnal EMBA. Universitas Sam Ratulangi, 5(2), 593-601.

Apriliastuty, W., Utomo, S. W., \& Sulistyowati, N. W. (2019). Apakah Audit Judgment Dipengaruhi oleh Ukuran Perusahaan, Tekanan Ketaatan, dan Pengetahuan Auditor? STATERA: Jurnal Akuntansi Dan Keuangan, 1(2), 1-13. https://doi.org/10.33510/statera.2019.1.2.1-13

Dana, A. La. (2019). Pengaruh Locus of Control, Framing, Tekanan Ketaatan dan Lopetensi Auditor terhadap Audit Judgment (Studi Empiris pada Kantor Akuntan Publik Kota Malang). E-Jra, 08(10), 116-130.

Ginting, W. A. (2019). Analisis faktor-faktor yang mempengaruhi audit judgment. ATESTASI : Jurnal Ilmiah Akuntansi, 2(1), 31-40. https://doi.org/10.33096/atestasi.v2i1.124

Indah Sari, D., \& Ruhiyat, E. (2017). Pengaruh Locus of Control, Tekanan Ketaatan Dan Kompleksitas Tugas Terhadap Audit Judgment. Jurnal ASET (Akuntansi Riset), 9(2), 23. https://doi.org/10.17509/jaset.v9i2.9230

Ismunawan, I., \& Triyanto, E. (2020). Faktor-Faktor Penentu Audit Judgement Pada Kantor Akuntan Publik (Kap Di Surakarta Dan Yogyakarta). Jurnal Akuntansi Dan Pajak, 20(2), 224-229. https://doi.org/10.29040/jap.v20i2.722

Kadir, N., \& Hasibuan, D. H. . (2017). Pengaruh Pengalaman dan Tekanan Ketaatan Terhadap Audit Judgment. Jurnal Ilmiah Akuntansi Kesatuan, 5(1), 058-065. https://doi.org/10.37641/jiakes.v5i1.18

Maryani, W., \& Ilyas, F. (2017). Pengaruh Skeptisme, Pengalaman Auditor Dan Self Efficacy Terhadap Audit Judgment. Jurnal Akuntasi, 7(3), 35-52.

Mukhyi \& Hendry. (2019). Pengaruh Gender, Tekanan Ketaatan, Idependensi, Tekanan Anggaran Waktu, dan Pengalaman Auditor Terhadap Audit Judgment. 4(2), 24-34.

Muslim, M., AR Pelu, M. F., \& KS, M. (2018). Pengaruh Kompetensi Auditor, Tekanan Ketaatan, dan Kompleksitas Tugas Terhadap Audit Judgment. Bongaya Journal for Research in Accounting (BJRA), 1(2), 08-17. https://doi.org/10.37888/bjra.v1i2.78 
Owner: Riset \& Jurnal Akuntansi

e-ISSN : 2548-9224 |p-ISSN : 2548-7507

Volume 05 Nomor 01, Februari 2021

DOI : https://doi.org/10.33395/owner.v5i1.316

Putri, A. R. (2017). Pengaruh tekanan anggaran waktu, kompleksitas tugas, pengetahuan auditor, dan pengalaman auditor terhadap. FEB RIau University, 4(1), 1282-1294.

Riantono, I. E. (2018). Faktor-Faktor Yang Mempengaruhi Audit Judgment: Studi Empiris Big Four Di Jakarta. Jurnal Kajian Akuntansi, 2(2), 178. https://doi.org/10.33603/jka.v2i2.1747

Rosadi, R. anggreani. (2017). Pengaruh Gender, Tekanan Ketaatan, Tekanan Anggaran Waktu, dan Pengalaman Audit Terhadap Audit Judgment. Jurnal Nominal, VI(1), 434-462.

Tampubolon, L. (2018). Pengaruh Tekanan Ketaatan, Pengetahuan, Dan Pengalaman Auditor Terhadap Audit Judgment. InFestasi, 14(2), 169.

https://doi.org/10.21107/infestasi.v14i2.4870

Yendrawati, R., \& Mukti, D. K. (2015). Pengaruh Gender, Pengalaman Auditor, Kompleksitas Tugas, Tekanan Ketaatan, Kemampuan Kerja Dan Pengetahuan Auditor Terhadap Audit Judgement. Ajie, 4(1), 1-8. https://doi.org/10.20885/ajie.vol4.iss1.art1

Yolanda, A. A. (2017). Pengaruh Tekanan Ketaatan, Tekanan Anggaran Waktu, Kompleksitas Tugas, Pengetahuan Dan Pengalaman Auditor Terhadap Audit Judgment (Studi Empiris Pada Auditor Inspektorat Provinsi Riau). Jurnal Online Mahasiswa (JOM) Bidang Ilmu Ekonomi. https://doi.org/10.1017/CBO9781107415324.004 